\title{
De amores, pasiones y violencia en el ejército, México siglo XIX
}

\section{Of Loves, Passions and Violence in the Army, 19th Century Mexico}

\author{
Claudia Ceja Andrade* \\ (1) https://orcid.org/0000-0002-3794-1803 \\ Facultad de Filosofía \\ Universidad Autónoma de Querétaro, México \\ claudia.ceja@uaq.mx
}

Resumen: Este trabajo tiene como objetivo estudiar las relaciones entre hombres y mujeres en el medio castrense mexicano durante el siglo xix, para reflexionar sobre las dinámicas de convivencia, las tensiones y conflictos de género, así como las maneras en que las autoridades militares actuaron e intervinieron, además de los significados sociales que se tenían sobre las mujeres y los hombres de la tropa.

Palabras clave: mujeres; ejército; violencia; género; siglo xix.

Abstract: This paper seeks to study the relationships between men and women in the Mexican military environment during the 19th century, to reflect on the dynamics of coexistence, gender tensions and conflicts, as well as the ways

* Líneas de investigación: historia social y cultural de las fuerzas armadas en México, siglo xIx; representaciones y prácticas sociales de las mujeres en los ejércitos mexicanos, siglos XIX y xx; prácticas de resistencia y negociación de los sectores marginales.

cómo citar: Ceja Andrade, C. (2022). De amores, pasiones y violencia en el ejército, México siglo xix. Secuencia (112), e1852. DoI: https://doi.org/10.18234/secuencia.v0i112.1852

cC Esta obra está protegida bajo una Licencia Creative Commons Atribución-NoComercial 4.0 Internacional. 
the military authorities acted and intervened in addition to the social meanings attached to people in the rank and file.

Keywords: women; army; violence; gender; 19 th century.

Recibido: 4 de mayo de 2020 Aceptado: 25 de enero de 2021

Publicado: 10 de febrero de 2022

\section{INTRODUCCIÓN}

Dos aspectos llamaron la atención de muchos de los invasores [americanos]. En primer lugar, la presencia de tantas mujeres que marchaban con los hombres: las soldaderas, esas que, al mismo tiempo, eran la fuente de una gran parte del apoyo logístico a los soldados mexicanos y la prueba de lo difícil que, en términos económicos, les resultaba a las mujeres sobrevivir en México sin la participación de su pareja.

Peter Guardino (2018).

$\mathrm{E}$ propósito de este artículo es examinar la forma como compartían la vida los hombres y las mujeres en el medio castrense mexicano a partir de una muestra de expedientes judiciales del siglo xIx; para ello se utilizaron 315 sumarios sobre procesos criminales realizados a miembros del ejército entre 1821 y 1860. En estos sólo se hallaron 174 filiaciones. Tomando los datos que arrojan dichas hojas de filiación, se realizó un cálculo porcentual del número de solteros (68\%), casados (26\%) y viudos (2\%) y del $4 \%$ se desconoce su estado civil (Ceja, 2018). También se incluyen datos de otras fuentes que rebasan esa temporalidad, con el fin de brindar mayores elementos para entender la forma de relacionarse dentro y fuera de los cuarteles.

Cabe destacar las limitantes de estas fuentes para mostrar dinámicas de vida o convivencia más allá de la violencia o la agresión hacia las mujeres, puesto que muchos de los expedientes se abrieron por estas razones. No obstante, a pesar de que la violencia de género estaba muy extendida y aceptada 
en la época, libros, diarios, novelas y periódicos pueden mostrar otros aspectos del mundo castrense mexicano y de la sociedad en su conjunto durante dicho periodo. También podemos mencionar que este artículo se inscribe en lo que sería la historia social y cultural de lo militar y la guerra, al señalar aspectos peculiares y distintos (como la presencia femenina) a diferencia de la historia más tradicional del ejército mexicano. ${ }^{1}$

$\mathrm{Al}$ iniciar el siglo xIx, México se vio envuelto en una serie de guerras de emancipación, luchas intestinas, invasiones extranjeras, pronunciamientos cívico-militares y demás problemas que duraron buena parte del periodo. En medio de este escenario convulso, una de las instituciones que cobró gran importancia para los gobiernos en turno fue el ejército, por lo que era indispensable contar con compañías de soldados lo mejor preparados: hombres profesionales, disciplinados, armados y bien suministrados de lo básico para entrar en acción cuando se requiriera. Sin embargo, las condiciones en que vivían los soldados en las filas del ejército estaban muy lejos de ser las ideales, lo que, al parecer, permitió una suerte de excepcionalidades dentro del orden militar como, por ejemplo, pasar por alto alguna infracción o delito de sus agremiados, aminorar el castigo, o permitir la compañía de las mujeres en el ejército, como lo veremos a lo largo de este trabajo.

\section{PALIATIVOS PARA LA VIDA CASTRENSE: MATRIMONIOS, UNIONES IRREGULARES Y AMANCEBAMIENTO}

Quienes estaban al frente de la institución castrense tenían que afrontar varias responsabilidades como la logística, el aprovisionamiento de víveres, la distribución de recursos económicos, etc., pero quizá el reto mayor era controlar a cientos de personas que tenían a su cargo. Estos hombres, quienes en su mayoría estaban en la flor de la vida, solteros y vigorosos, solían ser requeridos en el ejército; su condición de jóvenes los hacía tener un espíritu inquieto $\mathrm{y}$ aventurero que provocaba dolores de cabeza a sus superiores. Con uniforme

${ }^{1}$ Hay una amplia y nutrida bibliografía e historiografía desarrollada por notables estudiosos del ejército mexicano, como José Antonio Serrano, Juan Ortiz Escamilla, Conrado Hernández, Rodrigo Moreno Gutiérrez, Manuel Chust Calero, entre otros, pero sólo Peter Guardino (2018), en La marcha fúnebre, señaló la importancia de la presencia femenina en las filas de los ejércitos mexicanos durante la guerra de 1846-1848. 
y arma en mano, estos jóvenes cometían excesos en lugares públicos, bebían, reñían, robaban y cortejaban mujeres con quienes a veces se casaban o se juntaban. Estas situaciones que, en ocasiones, sus jefes inmediatos no podían controlar o dejaban pasar, se vivían como una realidad cotidiana, aun cuando existía una abundante legislación que sancionaba tales comportamientos.

Por lo que toca a los contratos nupciales, desde la época virreinal existió la preocupación por reglamentar esta práctica en el ejército a través de la Real Pragmática de Matrimonios, emitida el 23 de marzo de 1776, la cual pretendía controlar posibles nupcias entre españoles y mujeres americanas de calidad inferior, preservando así la jerarquía y el orden social. ${ }^{2}$ De acuerdo con esta disposición, si un oficial o un miembro de tropa (sargento, cabo o soldado) quería casarse tenía que entregar el permiso monacal acompañado de una evaluación hecha en Madrid y un "informe de calidad y circunstancias de la mujer con dictamen reservado", con el cual acreditaba su limpieza de sangre, su conducta recogida, así como el desempeño honesto de sus padres, posesión de bienes, la dote por parte de la mujer y renta del militar (Correa y Cáceres, 2012, p. 54).

Décadas más tarde, ya como nación independiente, la documentación que se les solicitaba a los miembros del ejército para contraer matrimonio mantenía básicamente la misma tónica que en la época virreinal, pues se les pedía la fe de bautismo de ambos contrayentes, los consentimientos paternos, además de la información legal de la conducta honesta y recogida de la interesada (Ordenanza, 1833, t. I, p. 478). ${ }^{3}$

Ahora bien, en caso de que el militar no entregara la documentación requerida y contrajera matrimonio sin la aprobación de la institución sería sancionado. En la legislación claramente se señalaba que aquellos oficiales,

${ }^{2}$ Una vez consumada la independencia, la legislación militar no fue modificada y prácticamente el ejército mexicano siguió normándose con ella durante buena parte del siglo xIx. Ana Lidia García Peña (2006) refiere que a lo largo de los siglos XVIII y xix hubo una serie de cambios sociales que dieron paso a un fortalecimiento del dominio masculino en la vida familiar; pues tanto la Real Pragmática de 1776 como la Real Cédula de 1803 dieron más autoridad al marido para administrar las correcciones domésticas y maritales; es decir, los problemas domésticos se restringían y se arreglaban en el ámbito privado.

${ }^{3}$ Las ordenanzas de 1842 y 1852 siguieron retomando la legislación española, véase: "quedará despojado del fuero militar el que cometiere delito de robo o amancebamiento dentro de la corte, y el que delinquiere en cualquier parte contra la administración y recaudación de mis rentas" en "Casos y delitos en que no vale el fuero militar". En Ordenanza (1842, t. II, p. 135); Ordenanza (1852, t. III, p. 108). 
sargentos y demás individuos graduados de oficiales serían depuestos de su empleo y privados del fuero. Asimismo, a los miembros de la tropa de guardia de infantería se les penalizaría de la siguiente manera: el sargento sería degradado a soldado sin tiempo preciso, el cabo serviría de soldado por seis años, y el soldado, además de que estaría preso un mes, se pondría como soldado último de la compañía sirviendo por seis años más (Ordenanza, 1833, pp. 342-343). ${ }^{4}$

Pero a pesar de las medidas punitivas los milicianos siguieron uniéndose con sus parejas en vínculos "ilegales"; lo cual en cierto sentido era por demás entendible, pues, como mencioné líneas arriba, muchos eran jóvenes solteros que comenzaban su vida adulta en lugares desconocidos y en un ambiente agreste como era el militar, por lo que parecía lógico que buscaran a personas que sirvieran de apoyo afectivo, material y de servicios. Por lo tanto, frente a estas necesidades, es posible que varios jóvenes hicieran todo el trámite requerido para casarse; pero si, por algún motivo, el permiso no era concedido, entonces se buscaban otros medios.

De tal suerte que estas uniones sin consentimiento oficial-conforme lo señalado en la legislación castrense-, sin lugar a dudas, estuvieron siempre presentes y fueron constantes, pero no fueron las únicas. El amancebamiento fue otra de las prácticas socorridas por esta población, y por lo que se puede observar, durante todo el periodo de estudio, pues era amplio el porcentaje de soldados que cohabitaban por las noches o vivían con alguien sin estar casados legalmente (García Peña, 2004, p. 648). ${ }^{5}$

Evidentemente la institución militar requería de jóvenes preferentemente solteros; como se ve reflejado en la información que arrojan los pro-

${ }^{4}$ Estas disposiciones se extrajeron tal cual de la orden de 18 de marzo de 1777 y de la Real orden de 31 de octubre de 1781. Algunos otros castigos que aparecen en la Ordenanza de 1833 son "Casamiento sin la concurrencia de los párrocos castrenses" y "Casamiento obligado por palabra de esponsales" y, prácticamente, el castigo para oficiales era deponerlos de su puesto, mientras que los soldados debían servir ocho años en su compañía (Ordenanza, 1833, p. 343).

${ }^{5}$ De acuerdo con García Peña (2004), en términos jurídicos, el amasiato o concubinato era la relación entre un hombre y una mujer solteros; en cambio, por adulterio usualmente se entendía la relación ilegal entre un hombre casado y una mujer soltera. Fuera de los márgenes legales las relaciones extramaritales de un hombre casado eran nombrados como amancebamiento, concubinato, barraganería, amasiato, queridato, contubernio, arreglo o lío. A la mujer que vivía con un hombre casado se le conocía como amante, amasia, amiga, querida, barragana, etc. (p. 648). Lo que pude observar en los procesos militares es que tanto fiscales, jueces y militares se referían a estas relaciones por el nombre de amasiato, independientemente de que los hombres estuvieran casados o no, y a las mujeres las llamaban amasias o queridas. 
cesos judiciales y las hojas de filiación, en las cuales se da cuenta que más de la mitad de los reclutas manifestaron estar solteros, mientras que sólo una tercera parte de la población dijo estar casada. Sin embargo, estos datos deben tomarse con precaución, pues debemos considerar que, aunque los jefes y autoridades de los soldados llegaron a tener conocimiento de que estos vivían con sus parejas sin estar casados, dicha condición no fue asentada en los formularios. Ahora bien, esto también pudo deberse a la falta de actualización de los archivos; puede ser que al momento de ser enlistados en las fuerzas armadas lo hicieron en condición de solteros y después contrajeron nupcias.

La existencia de las relaciones fuera del matrimonio era algo bastante común; unos lo decidían así porque no contaban con los recursos económicos para casarse; otros porque no tenían el permiso de los padres o tutores de la novia y preferían fugarse para obligar a la familia a dar el consentimiento; algunos más no consideraban el matrimonio oficial (católico) como una obligación, sino que optaban por apegarse a los usos y costumbres de sus propias comunidades en donde había un ritual nupcial, pero sin avenirse a la usanza cristiana, cuestión que fue mal vista por las autoridades (Guardino, 2018).

Así, aunque los soldados llegaron a declarar en las averiguaciones que hacían vida marital con sus mujeres sin estar casados, en las hojas de filiación jamás se mencionó nada al respecto, y al momento que las autoridades se enteraron de su transgresión tampoco sancionaron el hecho, tal y como lo indicaba la legislación militar; lo cual obliga a pensar que quienes expresaron vivir en amasiato, posiblemente fueron registrados como solteros, dado que no existía esa condición como figura legal; de ahí que se puede pensar que, posiblemente, esta práctica siempre estuvo presente. Por lo tanto, todo parece indicar que el concubinato fue el tipo de relación que más predominó en el sector militar, incluso por encima de las uniones irregulares. ${ }^{6}$

Ahora bien, si el concubinato y el casamiento (no sancionado oficialmente por el párroco castrense) prosperaron en el ejército, aun estando prohibidos, se debió a factores como la precariedad económica, los impedimentos de la familia o de las autoridades para llevar a cabo el matrimonio, o bien, por la dificultad de imponerse a las tradiciones de la gente. En todo caso, se advierte que también hubo un cálculo de quienes estaban al frente de la institución para permitirlo, pensando que mejorarían las condiciones de los sol-

\footnotetext{
${ }^{6}$ Entiéndase que nos referimos a aquellos realizados por otro párroco que no fuera el castrense, o aquellos consumados bajo las costumbres de sus pueblos.
} 
dados -en guarnición y en campaña- con la presencia de mujeres, a pesar de que también podían ser un factor de discordia.

El general Manuel Balbontín (1867) refería que "el abuso de llevar mujeres a la campaña, tanto los jefes y oficiales como la tropa, nació sin duda de la formación de las primeras fuerzas nacionales" (p. 92). Por su parte, Émile de Kératry, un militar francés que estuvo en México durante el segundo imperio, advirtió el hábito profundamente enraizado entre los miembros de los distintos ejércitos de llevar a mujeres consigo; pero a diferencia del general Manuel Balbontín -quien veía en la soldadera la representación viva del desorden y la indisciplina- Kératry entendió que su incorporación atendía más a la debilidad institucional que a las costumbres de la población, para él la soldadera era "la intendencia militar, sin ella, el soldado mexicano, tal vez, moriría de hambre"; pues estaban presentes en las filas de los ejércitos conservadores, los liberales y en las guerrillas: "Por la tarde encienden las mil cocinas del vivac, cantan, fuman; después se acuestan al aire libre mezcladas con la soldadesca. En el combate, ellas conservan sus puestos en la posta y marchan con un arrojo extraordinario." Para finales del siglo xix, Heriberto Frías confirmaba lo descrito por Kératry, y afirmaba: la vida de estas féminas transcurría entre el bullicio de la soldadesca, la brutalidad de las órdenes, los gritos, el redoble de tambores, los toques de diana, rancho y retreta. Vivían entre "chozas formadas y la pólvora de los combates" llevando agua y tortillas después de la batalla, "algunas rentaban cuartos que compartían con cuatro o cinco compañeras. Por las mañanas lavaban las cacerolas, ponían la lumbre, "regañaban al mocoso que se arrastra[ba] berreando" y, en un santiamén, "dejaban listo el almuerzo (chimole, frijoles, carne de puerco en chile verde, etc.) para salir corriendo al cuartel adonde llegaban jadeantes y sudorosas". ${ }^{8}$

Existen numerosos testimonios sobre la falta de personal para preparar la comida y hacer la limpieza. Los soldados terminaban resolviendo el problema, ya sea pagando para que alguien les atendiera y abasteciera de lo básico, o bien, buscando alguna mujer que quisiera hacer vida junto a ellos y se ocupara de esas labores. Pudo suceder que los militares no pensaran en

7 "La soldadera. Recuerdos de una campaña", fragmentos traducidos del libro de E. Keratry (1868). La contre guérrilla française au Mexique: souvenirs des terres chaudes / par le Comp. E. de Keratry. París: A. Lacroix, Verboeckhoven \& Ca., El Nacional, 3 y 10 de abril de 1887.

${ }^{8}$ Heriberto Frías, "Realidades del pueblo. La soldadera", El Demócrata, 10 de diciembre de 1895. En épocas tardías la novela Tropa vieja, del general Urquizo (1943), relata los milagros que estas hacían con el poco dinero que los soldados les daban. 
aquellas uniones como definitivas, sino que se valieran de ellas para facilitarse la vida en el ejército, y quizá muchos de ellos pudieran cambiar de pareja, con la expectativa de mantener una relación más o menos estable con la que mejor se acomodaran.

Así, el mundo militar también estaba predeterminado por las condiciones sociales marcadas por el género: los soldados, como hombres, requerían de la asistencia de mujeres para satisfacer sus necesidades y cuidarlos en caso de enfermedad, garantizando la funcionalidad de aquellos lugares como lo harían en cualquier otro hogar.

Los expedientes dan cuenta de que los soldados llevaron consigo a sus parejas y demás familiares; mientras que aquellos que llegaban a las compañías en calidad de solteros o viudos, al cabo de un tiempo establecían relaciones con mujeres que conocían dentro o fuera del cuartel, proliferando así el amasiato. ${ }^{9}$ Habría que preguntarse iqué tanto influyeron estas uniones para ayudar a aliviar la escasez de provisiones para la tropa y para disminuir el riesgo de deserción? y ¿qué tanto pudieron variar estas circunstancias a lo largo del tiempo $?^{10}$

Al menos para los años setenta y ochenta se pueden hallar opiniones a favor y en contra en la prensa acerca de la utilidad de las soldaderas para los hombres del ejército. Incluso los generales y jefes las consideraban en sus tácticas militares para marchar en la vanguardia o la retaguardia, y los médicos militares en campaña también se valían de ellas en las cirugías (García Figueroa, 1874, p. 33). Existía una fuerte polarización entre quienes estaban a favor de estas mujeres que acompañaban a los ejércitos y las veían como "ángeles

${ }_{9}$ No en balde los soldados mantenían sus propias estrategias para tener alimento diario. Carmen Gómez (1992, pp. 163-164) ofrece algunos ejemplos al respecto: cuando Alejandro O'Reilly visitó Puerto Rico en 1765 , dio cuenta de que los soldados vivían con mulatas a quienes entregaban el prest para que les hiciesen de comer, y que este ejemplo lo estaban siguiendo en otras compañías. Algunos otros inspectores identificaron que varios soldados vivían amancebados con mujeres empleadas en otros oficios, y compartían con ellas la comida pues les salía más barato. Por tanto, para que no se deteriorara más la disciplina se autorizó a los soldados casados a comer en sus casas cuando estuvieran libres de servicio.

${ }^{10}$ La urgencia de hombres para el servicio hizo que las sanciones no se aplicaran a quienes vivían en concubinato o en matrimonios ilegales. Carmen Gómez (1992) advierte que en la Cartagena del siglo XVIII se negociaba dicha condición otorgando licencia de matrimonio bajo el entendido de que la mujer perdería los derechos al montepío militar, dejándola desprotegida a la muerte de su cónyuge, lo cual le redituaba a la institución toda vez que ya no tenía que invertir un monto mensual en ellas (Correa y Cáceres, 2012, p. 57). 
bajados del cielo", por el empeño puesto para proveer de lo necesario a sus parejas, ${ }^{11}$ y quienes reprobaban enfáticamente eso:

Háse dicho que [...] las tales mujeres son hasta cierto punto benéficas, puesto que ellas proporcionan al ejército en campaña, los víveres necesarios a su subsistencia. Erróneas aseveraciones, si se comprende que esas mujeres viciosas, sin capital y sin la autorización de vivanderas, han robado y quitado a los pueblos y rancherías todo aquello con que se dicen auxiliar al ejército en campaña. Bien sabido es que al acercarse a cualquier población de indígenas algunas de nuestras fuerzas, la mayor parte de los habitantes, cuando no todos, huyen a los montes llevándose consigo a sus animales, por temor a la rapacidad de esas sierpes infernales que todo lo asuelan y arrasan sin miramiento alguno, pues no estando sujetas a la disciplina militar [icometen?] a veces a ciencia y paciencia de alguaciles, esa clase de criminales depredaciones. ${ }^{12}$

Es factible considerar que la continua necesidad de individuos para enviarlos a las filas del ejército, así como las circunstancias deplorables que se vivían en las compañías, fueron los principales motivos para que las autoridades no actuaran conforme a lo que dictaminaba la legislación en materia de concubinatos o uniones irregulares. Sin embargo, ello además permitió que los militares de todos los rangos aprovecharan dicha condición para engañar o maltratar a las mujeres, valiéndose del fuero militar y de la discrecionalidad de las autoridades al procesarlos, ya que a la institución le convenía más tenerlos en activo que enviarlos a prisión o darlos de baja por violentar o matar a sus esposas, amasias u amantes.

${ }^{11}$ "Charla de los domingos”, El Monitor Republicano, 8 de septiembre de 1872.

${ }^{12}$ Sr. Escobar, "Las soldaderas", La Sociedad. Periódico Político y Literario, 13 de septiembre de 1863 , p. 2. 


\section{DE AFECTOS, AMORES, DESAMORES Y OTROS PROBLEMAS EN EL EJÉRCITO}

[...] en los climas cálidos parece ejercer el hombre mayor tiranía sobre el sexo débil, y gusta de abandonarse a su cuidado, porque siente la continua necesidad del amor y del halago, que debilita en su alma los resortes de la energía.

Repertorio de Literatura y Variedades (1842).

Desde mediados del siglo xIX se advierte una creciente preocupación por la presencia de mujeres en el ejército. Los dramas protagonizados por los amores y desamores de los reclutas hicieron eco en los procesos judiciales a raíz de sus violentos desenlaces; mientras que la imagen de esas mujeres trascendió y se fijó en la "opinión pública" creando un nuevo concepto que hacía alusión a una nueva realidad femenina: las soldaderas. Las opiniones en torno a ellas fueron diversas, pues había quién las consideraba un mal necesario, pero hubo quien advirtió también que constituían la parte más negativa de las fuerzas armadas.

En 1863 el señor Escobar publicó un artículo en el periódico La Sociedad acerca de las soldaderas, en el cual describe las nefastas consecuencias que había traído su presencia en el ejército; pues si bien refiere que primero fueron unas cuantas esposas las que acompañaban a sus hombres en campaña, después de la independencia:

[...] fue poco a poco introduciéndose el abuso de ser ya crecido el número de mujeres que seguían a las tropas en sus marchas y en sus acantonamientos; y más adelante, en la administración del sr. Arista [¿Mariano Arista?], no sólo se permitió a esa clase de mujeres perdidas que siguiesen al soldado, sino que aun entrasen a dormir a los cuarteles: circunstancia que puso el colmo a este pernicioso y desmoralizador abuso. ${ }^{13}$

${ }^{13}$ Sr. Escobar, "Las soldaderas", La Sociedad. Periódico Politico y Literario, 13 de septiembre de 1863 , p. 2. 
Como era de esperarse, con este crecido número de mujeres en la vida de los militares, vino consigo otro problema que preocupaba cada vez más a los mandos superiores y a los médicos militares: las enfermedades venéreas, con las consecuentes pérdidas de efectivos útiles y vigorosos, además de los gastos económicos que ello implicaba (Carrillo, 2010, p. 73).

En 1857 el inspector del cuerpo médico militar propuso al gobierno establecer un concurso dirigido a la comunidad científica, con el fin de encontrar soluciones médicas a los padecimientos de la clase militar-particularmente en tierra caliente -, así como proveer métodos preventivos y terapéuticos para tratar la sífilis, puesto que constituía una de las enfermedades incapacitantes más comunes entre los miembros del ejército mexicano. ${ }^{14}$

En 1863, el inspector del cuerpo médico militar refería que la sífilis era la tercera enfermedad en importancia (por detrás de la fiebre tifoidea y la neumonía), a la cual consideraba "la reina en el ejército en todos los climas y en todas las estaciones", dado que la desarrollaba "su pasión favorita": las mujeres. ${ }^{15}$

En la década de 1870 el galeno Agustín García Figueroa (1874) realizó un trabajo sobre la sífilis entre los soldados acuartelados en la ciudad de México. A raíz de su investigación pudo observar que la población estudiada presentaba tres características, en primer lugar, era, en su mayoría, reclutada por leva; en segundo, provenían de varias partes del país, y tercero, buena parte de ella era soltera (p. 36). Para este médico, el hecho de que los soldados estuvieran varios años en un lugar de manera forzada, lejos de su terruño y en plena soledad, tarde o temprano provocaba que buscaran "instintivamente" una mujer que "los atendiera [y casi ningún] afecto [los estrechaba, y era] hasta cierto punto natural", toda vez que los unía más el "espíritu de asociación que de amor". Por lo que afirmaba que para ellos "la fidelidad de su querida" no importaba (p. 36).

Por su parte, el cuerpo médico militar dio cuenta en el Periódico Militar que el Hospital de Instrucción de la capital recibió a 141 enfermos de sífilis a principios de 1878, pero a lo largo del año ingresaron 975 efectivos para ser atendidos. Al finalizar ese año se registró que 989 fueron dados de alta y diez

14 “Cuestiones científicas", Diario de Avisos, 1857, p. 3. Al menos hasta 1867 parece que el tratamiento aplicado en los casos de sífilis se circunscribía a cauterizar las heridas.

15 "Informe del cuerpo médico militar al Ministerio de Guerra y Marina", El Siglo Diecinueve, 1863 , p. 3 . 
murieron. Mayo fue el mes en el que se registró menos ingresos con 37, y la mayor afluencia fue en abril con $128 \operatorname{casos}^{16}$ (véase gráfica 1 ).

El doctor Francisco Martínez Calleja (1887) señalaba que se habían recibido 7246 enfermos venéreo-sifilíticos en el hospital militar de 1875 a 1880 . Además, estimaba que el ejército estaba conformado por 40000 hombres, por lo cual "casi un tercio ha sufrido estas enfermedades y si, por otra parte, se piensa que estos individuos al reclutarse eran sanos, se llegará a la terrible conclusión de que nuestro ejército devuelve, después de 5 años una $3^{\text {a }}$. parte de su efectivo enferma" (p. 65). Quizá por ello, en 1881 el médico militar Francisco Montes de Oca calculaba que las enfermedades venéreo-sifilíticas afectaban como mínimo a un tercio, y como máximo a dos tercios de la población castrense, misma que se había atendido en el Hospital Militar de Instrucción (Carrillo, 2010, p. 72). Así también, entre 1881 y 1885 los hospitales militares reportaron haber atendido a 12886 infectados de sífilis (Rodríguez, 1891, p. 197). Ana Ma. Carrillo (2010, p. 73) asegura que únicamente el Hospital Militar de Instrucción atendió 1095 casos durante 1893, lo que constituía casi un tercio de su población.

Si la unión entre ambos sexos estaba fincada más en intereses personales (beneficios económicos, comodidad o privilegios que puede otorgar una relación) que en un afecto genuino, no significaba que todos estos hombres fueran indiferentes ante el comportamiento de sus parejas en turno; pues dentro de la lógica patriarcal, la relación se establecía en términos de respeto, obediencia y servicio de las mujeres hacia los varones. En ese sentido, los registros judiciales muestran algo distinto a lo dicho por el médico Agustín García, ya que la fidelidad tenía dos caras: la masculina y la femenina, y dependiendo de quién la cometiera podía tener o no importancia.

Culturalmente hablando el adulterio masculino era permitido; los hombres podían beber en exceso, acudir a prostíbulos, tener amantes e hijos fuera del matrimonio, compartir el lecho y la vida familiar con otras mujeres sin separarse de sus esposas (con o sin su consentimiento), y aunque podía haber una sanción legal o moral ante esta clase de comportamientos masculinos, tampoco significaban gran perjuicio hacia su persona. En cambio, el adulterio femenino ${ }^{17}$ se vivía de diferente manera; si ellas incurrían en tal conducta

${ }^{16}$ Periódico Militar, 1879, pp. 5-7.

${ }^{17}$ Controlar la sexualidad femenina era un imperativo de los sistemas de parentesco; resguardar los comportamientos que giraban en torno a la procreación y el comportamiento 
Gráfica 1. Enfermos de sífilis atendidos en el Hospital de Instrucción de la capital durante 1878

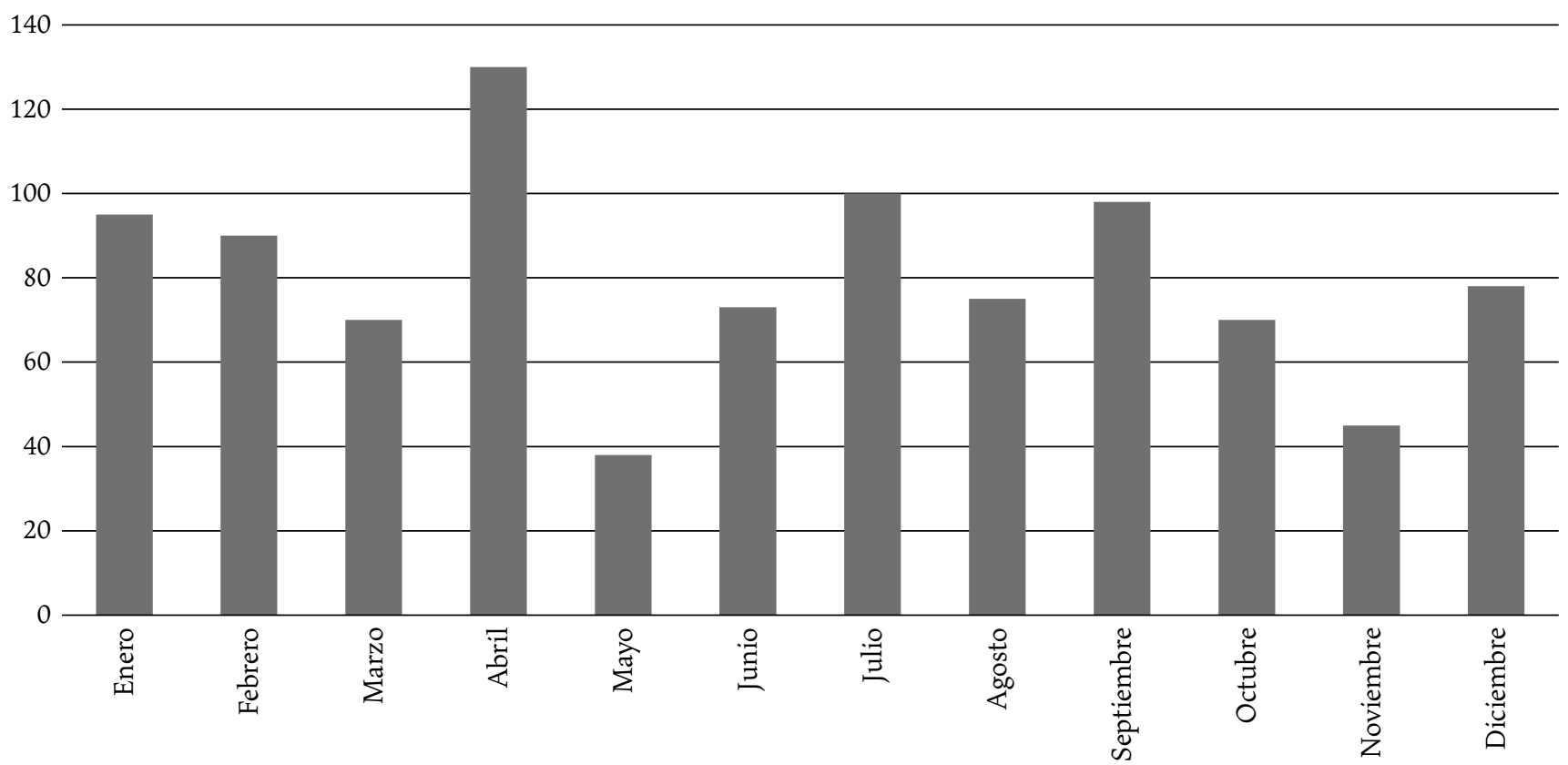

Fuente: Periódico Militar, 1879, pp. 5-7. 
o levantaban la más mínima sospecha, no era raro que fueran castigadas por sus compañeros, independientemente de que sintieran o no afecto por ellas.

Afuera o adentro de los cuarteles, los soldados conocían a mujeres con las que después harían vida marital; pero si por diversas circunstancias (incompatibilidad de caracteres, malos entendidos, adulterio, muerte, etc.) la relación llegaba a su término, generalmente ellas buscaban rehacer su vida en pareja, pues estar solas era complicado (en especial si se tenían hijos), e incluso solían vincularse con algún otro militar, ya que difícilmente podían salirse del medio castrense.

Las mujeres que estaban relacionadas con la vida militar eran mal vistas, porque además la mayoría pertenecían a las clases populares. Muchas de ellas habían sido llevadas a la fuerza por su pareja o por algún hombre que en alguna campaña las había robado de algún pueblo, las violaba y hacía vida marital con ellas. En caso de muerte de los militares era difícil que regresaran a sus casas, porque estaban alejadas de su lugar de origen, o porque ello implicaba luchar contra el estigma, el escarnio público y la marginación; por lo cual decidían quedarse a vivir al lado de la tropa con otro hombre. Algunas nacieron y vivieron ahí toda su vida.

Algunas veces una de esas soldaderas llora cerca de un cadáver ensangrentado, a tiempo que un regimiento pasa cerca de allí.

-Oiga Doña, grita un soldado - ¿qué tiene?

-Mataron a este, contesta ella llorando y mostrando el cadáver.

-Déjelo y véngase conmigo, dice el soldado.

Y ella coloca en el suelo cuidadosamente la cabeza del muerto que tenía en su regazo, se levanta y sigue al que la llama..$^{18}$

Sin embargo, la vida y las rupturas de pareja no eran del todo sencillas (en especial con hombres de "genio violento", como más de uno se describió), puesto que entrañaban tensiones en un contexto signado por una asimetría de poder entre los sexos y que, por supuesto, en un ambiente de hombres armados y empoderados por su oficio, fácilmente culminaban en desgracias

sexual de las mujeres servía para salvaguardar el linaje y la descendencia masculina. En consecuencia, menciona Ana Lidia García Peña (2006), "el adulterio femenino se convirtió en una gran afrenta contra los intereses de la sociedad patriarcal, que se encargó de condenarlo y castigarlo con dureza".

${ }^{18}$ Vicente Riva Palacio, "La soldadera”, México y sus Costumbres, 31 octubre de 1872, p. 2. 
donde usualmente ellas eran las víctimas, lo cual también trastocaba la vida militar.

Si los soldados u oficiales llegaban a enterarse de que sus antiguas compañeras tenían un pretendiente o estaban "en relación" con alguien, solían acosarlas o agredirlas, independientemente de si ellos eran quienes las habían abandonado o si estaban con otra persona. ${ }^{19}$ En 1842 Rafaela Salazar se encontraba presa y herida en la cárcel de la Acordada. Al interrogarla declaró:

[...] Que quien le rompió la cabeza fue un hombre que la encontró por la plazuela de Jesús [...] que este le habló y no habiéndole hecho aprecio cuando sintió, ya le había roto la cabeza sin saber con qué ni por qué; que no lo conoce ni sabe cómo se llama; que después que lo aprehendieron por el auxilio que ella pidió porque no fuera a llegar su esposo [que era soldado] y la encontrara golpeada, oyó decir que era sargento de Guanajuato, según dijeron en la Prefectura, de donde lo mandaron preso y a ella también. Que [este incidente] lo vieron varios que estaban presentes, pero que ella como no es de la tierra no conoce a ninguno, y que el sargento cuando le dio estaba borracho. ${ }^{20}$

El sargento Longino Martínez testificó que ese día había ido a beber aguardiente a una fonda con unos amigos encontrándose con Rafaela, quien, según sus palabras, era una "mujer de mal vivir con quien había tenido que ver hac[ía] tiempo", y como lo insultó, él le respondió con una pedrada. ${ }^{21}$ Es posible que ambos hayan tenido una relación tiempo atrás, de ser así, se puede entender el silencio de Rafaela, pues reconocer una relación con otro militar -y de mayor rango- podía dar pie a un conflicto con la pareja actual y más valía no mencionar nada. El sargento además aceptó haberla golpeado,

${ }^{19}$ Véase el proceso del soldado Juan Morato, quien encontró en la calle a una mujer "con la que había tratado unas cuantas veces [...] y como esta lo había engañado, luego que la conoció", delante del Alcalde y la tropa, la golpeó. Arrestada en el Principal, Juan se quedó a esperar que saliera. Indiferente Virreinal, caja 1706, exp. 23. Archivo General de la Nación (en adelante AGN), México.

${ }^{20}$ Sumaria averiguación contra el sargento $2^{\circ}$ de la $5^{\text {a }}$ compañía del batallón de Celaya, Longino Martínez, acusado de haber abandonado la guardia del presidio de Santiago Tlatelolco y de una herida que causó a Rafaela Salazar, 1842. Archivo de Guerra, vol. 116, exp. 1372. AGN, México.

${ }^{21}$ Sumaria averiguación contra el sargento $2^{\circ}$ de la $5^{a}$ compañía del batallón de Celaya, Longino Martínez, acusado de haber abandonado la guardia del presidio de Santiago Tlatelolco y de una herida que causó a Rafaela Salazar, 1842. Archivo de Guerra, vol. 116, exp. 1372. AGN, México. 
no sin antes mencionar que todo había sido producto del aguardiente que le "trastornó la cabeza" culpando a Rafaela, pues su sola presencia le "causó es[a] desgracia”. De la misma forma, y con el afán de evitar el castigo, Longino arguyó que sería "muy sensible que un soldado que ha servido mucho tiempo en la campaña de Texas y en otras varias, hoy se vea perdido por este acontecimiento". En la misma tesitura iba el alegato de su defensor quien subrayó premeditadamente la tosquedad y rudeza del sargento para minimizar lo acaecido con la mujer:

La poca educación civil y militar que ha recibido [el sargento], demostrada a primera vista con su ingenua confesión hace conocer que no tenía premeditación para cometer la falta en que incurrió, y prueba también esto, la sencillez con que en ella expresa los motivos que lo hicieron retirarse del destacamento [...] su encuentro impensado con unos arrieros paisanos suyos, acompañarlos a comer y embriagarse [...] le ocasionó involuntariamente la falta [...] El otro delito es haber estropeado a una mujer [pero ya está] enteramente buena. ${ }^{22}$

En la narrativa de estos sujetos se advierten los códigos de clase y género. ${ }^{23}$ Sacar a la luz que el sargento había ingresado como soldado, le sirvió al abogado para enfatizar el origen popular de su defendido, e implícitamente su ignorancia, y justificar todos sus actos: que Longino dejara la guardia del presidio de Santiago Tlatelolco para irse con sus amigos, que se embriagara y se relacionara con mujeres como Rafaela. Al parecer los alegatos del abogado tuvieron buen resultado, pues su cliente finalmente fue condenado a cuatro años de obras públicas por el delito de abandono de guardia y nada se comentó sobre la agresión a la mujer.

Ya fuera por su condición de género, su origen social o su situación económica, las mujeres vinculadas al sector militar padecían toda suerte de abusos. Algo que llama la atención al revisar los expedientes judiciales por violencia marital o doméstica -y que se observa también en el caso de Lon-

${ }^{22}$ Sumaria averiguación contra el sargento $2^{\circ}$ de la $5^{\text {a }}$ compañía del batallón de Celaya, Longino Martínez, acusado de haber abandonado la guardia del presidio de Santiago Tlatelolco y de una herida que causó a Rafaela Salazar, 1842. Archivo de Guerra, vol. 116, exp. 1372. AGN, México.

${ }^{23}$ Julia Tuñón (2008) sostiene que las asignaciones simbólicas para la construcción del género se definen a partir del contexto y la cultura; asimismo serán nutridas por las opiniones, las necesidades y expectativas, en este caso, que los hombres tenían de las mujeres. 
gino y Rafaela- es que al abrirse un proceso, los fiscales ponían más atención y sancionaban con mayor rigor las faltas militares, en comparación con la lenidad que trataban las agresiones y la violencia hacia las mujeres, o bien, si habían existido dos o más delitos (por ejemplo una transgresión doméstica y una infracción vinculada a lo militar) se abría el expediente por ambos casos, pero regularmente al infractor se le condenaba solamente por el delito militar. ${ }^{24}$

En ese sentido, los hombres hacían uso pleno de su fuero militar y de su condición de hombres, dirimiendo conflictos domésticos e inmiscuyéndose en los asuntos no sólo de sus compañeras sentimentales, sino también de sus madres, hermanas, hijas y de toda aquella mujer considerada de su pertenencia.

Los procesos habitualmente dan cuenta de cómo los militares exigían a otros cumplir con sus deberes, en espacios públicos o privados, así como respetar a su familia, su honor, etc., ${ }^{25}$ al tiempo que se observa cómo el sentir y la opinión de las mujeres se dejaron de lado, a pesar de haber sido partícipes directas o indirectas en los altercados.

Así, pues, independientemente del "espíritu de asociación" o amor, la fidelidad y la obediencia de ellas importaban más en la medida en que se ponía en riesgo el honor masculino. ${ }^{26}$ De ahí que en las averiguaciones apare-

${ }^{24}$ Sumaria contra Feliciano Castro, sargento $2^{\circ}$ de la compañía de granaderos acusado de haber inutilizado de un brazo, el 15 de junio, a Ana María Zavala y haber faltado a la subordinación al oficial de guardia de Prevención D. José María Ricoy de su misma compañía el 17 de enero de 1829. Archivo de Guerra, vol. 372, fs. 101-163. AGN, México. Ella mencionó que la golpeó sin motivo pues "no estaba ebrio". Asimismo, él dijo "que como a las siete de la noche llegó a su casa y la sacó a pasear y como tenía celos de ella, al llegar a una plazuela [...] inmediata a la pulquería de Juan Carbonero [le dio de palos]". El fiscal realizó su dictamen a partir del acto de insubordinación y nada mencionó sobre la agresión.

${ }^{25}$ Un ejemplo es el de un soldado del Batallón de Inválidos quien golpeó en la calle a su yerno Marcelino y a su amigo, quien era soldado porque aquel tenía problemas conyugales con su hija. Juan José Álvarez, soldado del Batallón de Inválidos, por herir al artillero, José María Ortiz de la $5^{a}$ compañía de la $1^{a}$ brigada de artillería permanente, así como también al paisano Marcelino Labrada, la tarde de junio de 1837. Archivo de Guerra, vol. 4, exp. 37. Archivo de Guerra, México; Averiguación sumaria sobre las heridas inferidas a Mónica González por el soldado del 1er. batallón activo, Juan Rodríguez. Archivo de Guerra, vol. 14, exp. 111. AGN, México. Juan llevaba a dormir a su casa a su compañero el soldado Fernando Villa. Una noche, Juan golpeó a su cuñada Mónica porque, según él, tenía amoríos con Villa.

${ }^{26}$ Véase la "incomodidad doméstica" entre un teniente y su esposa, quien, por no tener el ponche a tiempo, discutieron. Él declaró que: "por tener el genio violento y no pegarle a su esposa se hirió él mismo" con un puñal que estaba encima del bracero, diciéndole: "para que no te dé yo más guerra, y se acaban los disgustos y todo". Averiguación sumaria sobre la herida que se infirió el teniente del $2^{\circ}$ batallón activo de México, D. Agustín Márquez. 1835. Archivo de Guerra, vol. 30, exp. 246. AGN, México. 
cieran descripciones sobre discusiones o peleas entre ellos, aunque, como lo he mencionado, las causas se abrían por otras circunstancias.

$\mathrm{Al}$ respecto, mostraré dos ejemplos. En enero de 1843, el soldado Sebastián Virgen fue golpeado por el centinela Pedro Reséndiz, empleado en la guardia del palacio, porque en el patio principal estaba sentada la mujer de Reséndiz, quien lo esperaba para darle de comer. Virgen, quien además estaba ebrio, se acercó a ella poniéndole la mano en la cabeza, diciéndole "una expresión amorosa”. Al ver esto, Reséndiz enfureció pues Virgen se acercó a su mujer queriéndola "manosear", por lo que le gritó que era un cabrón, dándole dos cañonazos y preparando el arma para dispararle, mientras que Virgen respondía que no sabía que "aquella mujer era suya". ${ }^{27}$ Nuevamente, lo que hallamos en este desencuentro entre el soldado y el centinela es la clara condición de propiedad y de subordinación que los hombres ejercían sobre las mujeres, así como la necesidad de defender mediante el uso de la fuerza física "esa pertenencia y ese derecho".

El segundo caso fue la riña entre los sargentos Luis Anaya y Victoriano Camacho por las heridas que el primero le infirió al segundo la noche del 25 de marzo de 1843. El motivo era que Dolores Ballesteros para esos momentos era pareja de Anaya y tiempo atrás había salido con Camacho, lo que dio paso a que este buscara a Anaya para "reconvenirle por las relaciones de amistad en que actualmente estaba con la expresada Ballesteros" ${ }^{28}$ De este caso salta a la vista que, durante todo el proceso, tanto el fiscal como los abogados jamás llamaron a la mujer por su nombre, sino que se referían a ella como "la Ballesteros". La argumentación y la forma de exponer el caso parecía indicar que su doble amasiato le restaba credibilidad y la convertía en la principal culpable; Dolores estuvo en prisión nueve meses, al parecer, porque en medio del conflicto tomó a Camacho del brazo impidiéndole defenderse.

${ }^{27}$ Causa formada contra Sebastián Virgen, soldado de la $1^{a}$ compañía del batallón activo de granaderos de la guardia de los supremos poderes, acusado de haberle faltado a un centinela y haber herido a un soldado el 7 de enero de 1843. Archivo de Guerra, vol. 195, exp. 1971. AGN, México. No se tomó declaración de la mujer.

${ }^{28}$ Toca a la causa instruida al sargento del 3er regimiento de infantería Luis Anaya por haber herido alevosamente al de su misma clase Victoriano Camacho. Archivo de Guerra, vol. 210, exp. 2133. AGn, México. El Consejo de Guerra sentenció a Anaya a diez años de presidio, pero la Comandancia General de México se inconformó. Se desconoce si se cumplió con la sentencia del Consejo. 
Las ideas, creencias y prejuicios de jueces y fiscales sobre el comportamiento de la tropa y de sus mujeres influían en los castigos que imponían, así como en los resolutivos o sentencias que emitían. ${ }^{29}$

Jueces, médicos, periodistas y autoridades coincidían en que la principal causa de la violencia entre los militares era por las mujeres; pero también era cierto que en medio del conflicto, y cuando la situación así lo ameritaba, no sólo sus parejas sino también sus madres, hermanas e hijas eran solidarias con ellos. Es decir, a pesar de las relaciones desiguales y de subordinación en que vivían, hombres y mujeres se necesitaban; todavía más en plena vida castrense, creándose lazos que mostraban el papel colaborativo y de apoyo entre ambos.

Las soldaderas proveían con aguardiente a sus hombres, en ocasiones, se escabullían en los cuarteles para sacar las prendas de munición, el armamento y las paradas de cartucho, para venderlas. Se convertían en parejas y cómplices de ellos; se instalaban en las cercanías de los cuarteles y se agolpaban en las puertas para saber de ellos, esperarlos a su salida o abastecerlos de lo necesario. ${ }^{30}$

En 1873 el periódico El Foro daba cuenta de la reclamación hecha por la mujer del soldado Arcadio Serrano en el 2o. Distrito, quien pedía el amparo para este por los palos que el teniente coronel López le había dado. Además, agregaba la nota: "Sabemos también que ante el mismo juzgado han promovido amparo las mujeres de otros soldados que, contra su voluntad y de leva, han sido puestos al servicio militar; que por haber apelado a la justicia federal, se les priva de hablar con sus familiares, se les acorta el prest y amenaza con mandarlos a Yucatán o Isla de Caballos si no desisten de su petición de amparo." 31

${ }^{29}$ Había un consenso generalizado que veía con malos ojos a las mujeres de los soldados y muchos compartían las ideas manifestadas por el médico militar Agustín García Figueroa (1874): "La mujer, bajo en la forma en que se le halla en los cuarteles, no tiene de mujer más que el sexo; es el aspecto más repugnante en que se puede encontrar a la mujer degradada; bajo esta forma pierde su prestigio a los ojos del hombre, y si éste, está condenado a no tener relaciones más que con esta clase de mujeres, se halla eminentemente predispuesto a los vicios contra-natura".

${ }^{30}$ En 1874 una soldadera llamada Máxima Robles apuñaló al capitán $1^{\circ}$ de Distrito, José María García, cuando este impidió que introdujera a las cuadras de las tropas, las tripas con aguardiente que llevaba ocultas. La Voz de México. Diario Político, Religioso, Científico y Literario de la "Sociedad Católica", 16 de agosto de 1874, p. 2.

${ }^{31}$ El Foro. Periódico de Jurisprudencia y de Legislación, 19 de diciembre de 1873, p. 612. 
Igualmente, las mujeres llegaron a apoyar a sus hombres o familiares reclutas para desertar y huir de las fuerzas armadas. Una muestra es la causa que se abrió el 6 de mayo de 1859 por la muerte del sargento Francisco Martínez. La viuda Micaela Galván declaró que el sargento Justo Serrano había citado a Martínez para que fuera al callejón de la Plazuela del Árbol, lugar donde más tarde lo mataría. ${ }^{32}$ Cuando se llevó a cabo el proceso, el sargento Serrano se fugó con otro de sus compañeros. Al hacer la averiguación se descubrió que Manuela Juárez y Juana Olivares los habían ayudado a escapar, pues tenían acceso al cuartel y al calabozo. La mujer del soldado Cleofás Soles confirmó estas versiones, porque vivía enfrente y vio cuando los cuatro salieron corriendo del lugar.

Soldados, cabos, sargentos y algunas mujeres fueron llamados a comparecer. Por sus declaraciones se advierte el apoyo, así como la relación cercana que estas mujeres mantenían, no sólo con los prófugos, sino también con el resto de los miembros, pues varios dijeron que conocían a las mujeres que huyeron con los prófugos, pero no sabían sus nombres, señal de que frecuentaban el cuartel. ${ }^{33}$

Con base en los casos estudiados podría decirse que, al menos durante el periodo de estudio, estos hombres de armas siempre necesitaron de ellas, y en caso de algún exceso o exabrupto, sabían que el fuero militar constituía un gran amparo para disminuir o eximirse del castigo, por lo cual se valieron de este de forma abierta o discrecional, pues cuando se veían imputados en un proceso judicial, no tardaban en referir su condición de militares o desertores. Por su parte, la opinión del médico García, quien afirmó que estos sujetos no tuvieron el más "mínimo aprecio" por sus esposas o concubinas, muestra claramente los esquemas sociales y prejuicios acerca de lo que debía ser la feminidad, y los comportamientos aceptados o sancionados para que las mujeres se hicieran querer por los hombres.

32 Toca a la causa instruida al sargento $2^{\circ}$ del batallón de ingenieros Justo Serrano por homicidio. Archivo de Guerra, vol. 390, exp. 4092. AGN, México. Se intentó confrontar la declaración de Micaela con la del cabo Mazo, pero había "desaparecido". El sargento Martínez murió horas después. Estaba ebrio y no quiso delatar a Serrano.

${ }_{33}$ Toca a la causa instruida al sargento $2^{\circ}$ del batallón de ingenieros Justo Serrano por homicidio. Archivo de Guerra, vol. 390, exp. 4092. AGN, México. Para adentrarse en las relaciones de colaboración, resistencia y poder entre mujeres y hombres, véase Stern (1999). 


\section{RELACIONES CERCANAS, VIGILANTES Y VIOLENTAS}

Ana Lidia García Peña (2006) ha argumentado que, la gran concentración de poder que acumularon los miembros de las fuerzas armadas durante el siglo XIX favoreció una suerte de militarización de la vida política y pública; lo que a su vez trajo como resultado un incremento de los actos delictivos atribuidos a este sector, en buena medida, porque el fuero militar y la actuación discrecional de las autoridades (por la urgencia de hombres) fueron los principales factores que favorecieron la impunidad. ${ }^{34}$

Al revisar los juicios promovidos contra militares por agresiones o conflictos en los que estaban involucradas las mujeres, se puede advertir que las sumarias por abuso sexual o violación a desconocidas eran menos, en comparación con aquellos casos en donde existía un lazo familiar o un vínculo afectivo con la agredida. ${ }^{35} \mathrm{Si}$ la violencia a las mujeres desconocidas se denunció poco, quizá tenía que ver con una impartición de justicia que, de antemano, se sabía inclinada a favorecer a los miembros del ejército. También pudo ser que los protegían porque a la institución le convenía más tener a sus soldados en campaña, que en las cárceles. Ante tales circunstancias, varias mujeres prefirieron olvidar el agravio a tener que enfrentarse a interrogatorios de los fiscales, la descalificación pública, además de los reproches o agresiones de sus cónyuges y demás familiares. ${ }^{36}$

En los casos por violencia en casa sucedió algo parecido. Aunque las esposas, amasias o amantes tampoco denunciaban lo que Heriberto Frías definía como los "bofetones e ingratitudes de su viejo", y dado que el trato era cotidiano y de mayor confianza, las "incomodidades domésticas" -como acostumbraban a llamar a esta clase de agresiones- era tan comunes que se tendía a restarles importancia; pero al cabo de un tiempo, muchas de estas

34 Para el caso específico sobre la violencia perpetrada por militares hacia sus esposas, véase García Peña (2006, cap. 2, pp. 59-86).

35 De modo tal que las formas de relacionarse durante esta época eran bastante parecidas a las del periodo virreinal; pues como bien demostró Steve J. Stern, los ataques sexuales, a diferencia de lo que siempre se había pensado, eran cometidos por gente cercana: familiares o conocidos, y no propiamente por extraños (Stern, 1999).

${ }^{36}$ Sumaria averiguación sobre el robo cometido a María Josefa Juárez por unos soldados de infantería de la guarnición, 1837. Archivo de Guerra, vol. 4, exp. 39. AGN, México. 
relaciones se volvían demasiado violentas, por lo cual eran ventiladas en los juzgados militares.

Por su parte, faroles, comerciantes y transeúntes daban aviso a las autoridades sobre mujeres inconscientes o sin vida en callejones o vecindades de la ciudad, víctimas de sus compañeros. Y, evidentemente, si estas conductas sucedían en el ámbito público, en el doméstico eran todavía más comunes. Durante el día o la noche se escuchaban ruidos, gritos, llantos y golpes en las habitaciones y casas, por lo que vecinos o familiares no dudaban en llamar a las patrullas de seguridad para calmar los ánimos.

Una vez que llegaban al lugar, los miembros de la policía o los vigilantes pedían informes, quedando en calidad de detenidos los agresores, víctimas y hasta los "mirones". Delante del alcalde u otra autoridad, algunos testigos sugerían tímidamente que estos hombres no sólo les daban una mala vida a sus cónyuges, sino que también amedrentaban a los vecinos escudándose en sus insignias, ${ }^{37}$ razón por la cual varios preferían no denunciar y evitar problemas, ya fuera porque eran sus familiares, vecinos o trabajaban para ellos, y si eran llamados por las autoridades como testigos, preferían faltar a las audiencias, ocultándose o cambiándose de domicilio.

En la investigación que se le practicó al teniente Mariano Zapata por golpear a su esposa, Rosa Castro, se advierten las ideas que él tenía sobre la infidelidad, así como el tipo de relaciones que seguramente estableció en su cotidianidad. El teniente le dio "infinitos cintarazos" a Rosa por haber ido a planchar un chaleco a casa de su hermana, a pesar de que se lo tenía prohibido, pues prefería verla "en un congal que en casa de sus parientes, esto lo hacía con el objeto de que no les contase la mala vida" ${ }^{38}$ Las agresiones en este matrimonio trascendieron la esfera privada, ya que no era la primera vez que sucedía; el cirujano Miguel Uribe atendió a Rosa por lo menos tres veces. Y los golpes que recibió la noche del 3 de febrero de 1823 fueron en presencia del

${ }^{37}$ Véase el caso de Guadalupe, quien tuvo una discusión con su vecina, Gertrudis Flores, esposa del capitán, José Reyes, quien, por dicho conflicto, la lastimó cortándole el brazo. Sumaria al capitán agregado al regimiento número 11, don José Reyes, en averiguación de la herida inferida a doña Guadalupe Alejarzado, 1825. Archivo de Guerra, vol. 180, exp. 1840. AGN, México. Él y Gertrudis compartían casa con otro capitán y su esposa.

38 Averiguación de las heridas que el teniente de la $4^{\mathrm{a}}$ compañía del batallón y regimiento dicho don Mariano Zapata perpetró a su esposa doña Rosa Castro la noche del 3 de febrero de 1823. Archivo de Guerra, vol. 186, exp. 1870. AGN, México. 
asistente del teniente, Abundio Calderon, y otras dos mujeres de la vecindad. La joven narró al fiscal los maltratos que recibía de Zapata:

Que en otra ocasión yendo para Zitácuaro la tomó por el pelo y la colgó en la cabeza de la suya yendo a caballo habiéndola arrastrado gran trecho, otra vez la colgó de un árbol azotándola hasta acabarle tres varas en el cuerpo, que otra ocasión casi le arranca la punta de la nariz de una mordida como lo acredita la cicatriz que se le ve, que de resultas de los muchos golpes que ha sufrido se ha contraído uno al corazón que cuando la acomete la priva de sus sentidos y entonces su marido se sube encima y le patea el estómago [...] cuyos hechos constaban en el proceso [...podrá declararlo la] criada que tuvo [...] que hallándose enferma sin tener quien la asistiera condolido su padre de su miseria le mandó a su casa a su hermana, niña doncella a quien su esposo quiso forzar [...] reservándose más cosas. ${ }^{39}$

El ejercicio de la violencia era resultado del orden patriarcal el cual permitía a los hombres "reprender" a sus mujeres cuando se creía que ellas se habían apartado de los cánones socialmente establecidos -y su voluntad por controlarlas-, lo que sucedía en toda la sociedad del México decimonónico. El maltrato era aceptado como correctivo cuando no era excesivo; es decir, estaba aprobado mientras no trascendiera el ámbito privado, y también porque existía una normativa que lo amparaba. ${ }^{40}$ De cualquier manera, la violencia perpetrada por los militares hacia sus mujeres llegó a incomodar a algunos; por ejemplo, el asistente del teniente Mariano Zapata declaró todo lo que llegó a ver en las noches en que se quedaba a dormir en la casa del oficial comentando con asombro como:

las paredes de su casa estaban manchadas de sangre [...] movido de compasión en ver a la expresada con su niño en cueros sin más cama que un petate [...] levantándose muy de mañana a recoger la manta y la mochila temeroso que su

${ }^{39}$ Averiguación de las heridas que el teniente de la $4^{a}$ compañía del batallón y regimiento dicho don Mariano Zapata perpetró a su esposa doña Rosa Castro la noche del 3 de febrero de 1823. Archivo de Guerra, vol. 186, exp. 1870. AGN, México.

${ }^{40}$ Ana Lidia García Peña (2006, p. 69) explica que la sevicia podía definirse de dos maneras en la legislación colonial: 1 . Grave y atroz. 2 . Continua. En cambio, la ley del matrimonio civil de 1859 suprimió el maltrato continuo, dejándose sólo la violencia grave o atroz, lo que en términos jurídicos significó un retroceso para las mujeres. 
teniente la viera y le pagase, que varias ocasiones tuvo que darle su sueldo para el gasto de tres reales diarios a cuatro [...] más su expresado teniente no podía alcanzarle para todo lo que pedía le diese de comer pues quería de almorzar chocolate, pan con mantequilla y torta de huevos, por lo que el día que el gasto no le alcanzaba, le pegaba de patadas y manazos tomándola por el pelo y arrastrándola por la sala diciéndole que era una puta arrastrada que se mudara de su casa pues se le hacía pesado el estarla manteniendo. ${ }^{41}$

Aunque la esposa del teniente decidió exponer una a una las agresiones de que era víctima, ella estaba convencida que el maltrato era por una "amistad ilícita" que su esposo llevaba con una mujer llamada Guadalupe. Así, delante de fiscales o jueces, los perpetradores solían justificar sus agresiones e infidelidades tanto por el temperamento violento que los caracterizaba, como por la debilidad de su sexo; mientras que ellas aceptaban que la infidelidad de sus hombres era producto de su naturaleza débil, por lo cual identificaban a sus amantes como las verdaderas culpables de su mal proceder, llamándolas "cócoras" o "putas", porque andaban "muy santas con sus maridos después de que han andado tanto tiempo en picardías".

Las explicaciones que las mujeres exponían en sus declaraciones acerca de los exabruptos y "acaloramientos" de sus parejas no deben entenderse como meras justificaciones, sino como discursos producidos dentro de un sistema y una cultura patriarcal en la que ellas y sus parejas estaban insertas. La violencia conyugal hacia las mujeres estuvo ampliamente difundida en la sociedad decimonónica mexicana, por lo cual trascendía el ámbito exclusivamente militar (García Peña, 2006). En otras palabras, a pesar de que en las narrativas hombres y mujeres eran diferentes, correspondían al mismo entramado ideológico donde se entrelazaban y correspondían, al ser objetos de la misma cultura que subyacía alrededor de ambos.

La entrada y salida de hombres y mujeres a los cuarteles generó una compleja red de vínculos de todo tipo. Estas cercanías entre el cuartel y la casa daban pie a que se diluyeran los límites entre un espacio y otro, favoreciendo todo tipo de relaciones de carácter formal e informal en ambos; las mujeres solían estar siempre presentes ofreciendo toda clase de servicios y apoyos,

${ }^{41}$ Averiguación de las heridas que el teniente de la $4^{\mathrm{a}}$ compañía del batallón y regimiento dicho don Mariano Zapata perpetró a su esposa doña Rosa Castro la noche del 3 de febrero de 1823. Archivo de Guerra, vol. 186, exp. 1870. AGN, México. 
como vender o preparar alimentos, curar enfermos, lavar ropa, llevar comida a la cárcel o al cuartel, etc., lo cual provocaba la molestia y la ira de sus parejas, quienes no toleraban estas ni otras situaciones, porque daban paso a que anduvieran en la calle todo el tiempo, platicaran con extraños, salieran sin permiso, llegaran tarde al almuerzo, etc. ${ }^{42}$ Lo anterior levantaba las sospechas de aquellos celosos compañeros dando lugar a "excesos de frenesí" y "calentamientos de cabeza", pues al sentirse "ultrajados por la persona a quien reputaban su mujer", terminaban golpeándolas o privándolas de la vida. ${ }^{43}$

Ante estas circunstancias, y dada la cercanía entre el cuartel y la casa, así como el trato cotidiano entre sus habitantes y los militares, hubo ocasiones en las que vecinos, soldados y ayudantes de los oficiales no mencionaron nada sobre estas "incomodidades" por miedo a represalias. En ese sentido, el abuso de autoridad de los hombres y la indefensión en que vivían estas mujeres frente a una justicia militar -la cual sólo miraba por el bienestar de sus agremiados y la institución- formaban parte de la violencia estructural que vivían, no sólo ellas, sino también familiares y personas cercanas a los militares.

Por último, quisiera referir el caso de Luz Flores. Si bien la exposición de los hechos es amplia, me parece que este proceso nos ofrece un ejemplo de las características que he señalado a lo largo de este artículo: la vida cotidiana de estas mujeres en el ejército, sus relaciones y los vínculos que creaban, el abuso de poder, así como la desprotección legal de estas ante una justicia que actuaba de manera discrecional y, en la mayoría de los casos, a favor de los militares.

El proceso se promovió el 3 de enero de 1839 cuando Luz, joven de 16 años, se escapó de su casa y dos mujeres -Santos Rodríguez y Soledad Vega- la ocultaron. Sin embargo, el sumario llevó más tiempo de lo previsto, pues Luz declaró que, si se había ido de su casa, fue porque su padrastro, el

${ }^{42}$ Brígida Hernández fue golpeada por su esposo porque le tenía "prevenido [que] no fuese a la cárcel de la Acordada a llevarle a su compadre Bruno Brito comida o almuerzo en razón de que estaba sospechoso de ellos, estas incomodidades las ha tenido en repetidas ocasiones"; en Sumaria mandada instruir al soldado de la $1^{a}$ compañía del expresado cuerpo, José María Valverde por cierta herida que le infirieron. 30 de agosto 1842. Archivo de Guerra, vol. 195, exp. 1963. AGN, México.

${ }_{43}$ Sumaria averiguación formada al soldado de la $1^{a}$ compañía, Crescencio Hernández, por las heridas que infirió en la persona de Marcelina Chavarría. Archivo de Guerra, vol. 140, exp. 1536. AGN, México. La hirió porque le molestó que no saliera cuando le chifló. 
sargento Amado Flores, abusaba de ella desde los siete años y, en ocasiones, la golpeaba. ${ }^{44}$

La joven tenía una relación sentimental con Agustín Torres, joven de catorce años y tambor de la misma compañía a la que pertenecía su padrastro. La chica confesó que hacía dos semanas mantuvo una "amistad ilícita" con él, y que este la había exhortado a que "se largara del lado de su padre, manifestándole que le pondría su cuarto y la mantendría con su socorro". Por su parte, Agustín narró que la había conocido en el cuartel cuando iba a dejarle los alimentos al sargento, e "inspirándole cariño la comenzó a seguir con el objeto de tener amores con ella". Intentaron ser discretos para no levantar sospechas entre los miembros de la compañía, él la esperaba en la calle cuando Luz iba a dejar la comida a su tío, quien trabajaba en la panadería de la Mariscala. ${ }^{45}$

Agustín escondió a Luz en casa de su compañero, el tambor Gabriel Santos, quien vivía en el callejón de las Cueritas, pero su esposa, Santos Rodríguez, no quería que Gabriel se metiera en problemas con el sargento, razón por la cual la sacó de su casa y la llevó a "depositar" con la portera Soledad Vega. Al parecer, los jefes del tambor fueron quienes delataron a los jóvenes, avisándole al sargento dónde estaba su hijastra. ${ }^{46}$

Sin duda, para vivir en cualquier comunidad es indispensable conocer y contar con parientes, vecinos y amistades que constituyan redes de apoyo en todo momento. Con todo, los lazos y afectos que se crean entre sus miembros pueden convertirse en pesados lastres, una vez que se vuelven ojos escudriñadores de acciones y comportamientos ajenos. De ahí que el anonimato que ofrecen las grandes urbes contemporáneas hace una gran diferencia;

${ }^{44}$ Causa instruida contra el sargento $1^{\mathrm{o}}$ supernumerario de la $3^{\mathrm{a}}$ compañía, Amado Flores, acusado de incesto en la persona de Luz Flores. Archivo de Guerra, vol. 32, exp. 261. AGN, México. El abuso fue reconocido por dos matronas quienes examinaron a Luz.

${ }_{45}$ Todo parece indicar que la precaución que tomaron sirvió de poco pues, según el sargento Amado, "la mayor parte de los individuos del cuerpo han visto que su referida hija buscaba al tambor en cuanta parte entraba de servicio"; en Causa instruida contra el sargento $1^{\circ}$ supernumerario de la 3a. compañía, Amado Flores, acusado de incesto en la persona de Luz Flores. Archivo de Guerra, vol. 32, exp. 261. AGn, México.

${ }^{46}$ El sargento, José María García, mencionó que Luz "se largó del lado del poder con el tambor Torres, lo cual todos los individuos del cuerpo lo saben porque ambos se paseaban con el mayor descaro". Otro sargento, Buenaventura Corona, dijo también que la había visto en la Villa de Guadalupe con el tambor Torres "paseándose públicamente, como lo vieron muchos otros del cuerpo, en Causa instruida contra el sargento $1^{\circ}$ supernumerario de la $3^{a}$ compañía, Amado Flores, acusado de incesto en la persona de Luz Flores. Archivo de Guerra, vol. 32, exp. 261. AGN, México. 
sin embargo, en el siglo xIx, la ciudad de México figuraba como una ciudad donde todo se sabía y todos se conocían, más aún, si pertenecían a ciertos gremios o sectores, como lo era el ejército, en donde se compartía no sólo el oficio, sino también el día a día. Noticias, rumores y toda clase de chismes corrían como pólvora generando una vigilancia casi omnipresente, la cual a su vez era aprovechada por sus superiores y jefes para controlar a sus subalternos, sus familiares y a sus mujeres.

Si Agustín tuvo la confianza de llevar a Luz a casa de Gabriel fue porque tenía una "amistad muy estrecha" con él, probablemente cultivada en el batallón. Estos vínculos eran muy significativos pues creaban una solidaridad de cuerpo, compadrazgos, uniones matrimoniales, etc., al tiempo que servían para enfrentar o darle vuelta al poder de los mandos superiores. Sin embargo, no debemos olvidar que, así como los soldados establecían relaciones afectivas con otros compañeros, sus jefes más inmediatos también lo hacían, y en ciertos casos, tal como lo demuestra esta sumaria, no sólo se valían de las relaciones y las amistades que hacían en el cuartel, sino que también hacían uso del poder que tenían.

El sargento Amado Flores explicó que antes de ser relevado "ya tenía noticia de que su hija esta[ba] en poder del tambor", pues se lo habían dicho los sargentos José María García y Buenaventura Corona. Amado fue a buscarla sin resultado alguno. Al regresar al cuartel, Flores se encontró con el sargento Mariano Méndez, quien le advirtió que no lo hicieran "guaje” pues "su hija se hallaba en poder de [la] casera [de Gabriel]". Según su testimonio, "por efecto de la casualidad fue a la casa número dos del callejón de Cueritas donde estaba oculta la citada muchacha", dándole aviso al sargento Flores para "[calmarle] la aflicción y [...] por un deber de la estrecha amistad que ha tenido con él". ${ }^{47}$

Al ver que todos sus esfuerzos habían sido fallidos, y dar cuenta del gran poder que su ofensor poseía, Luz, en pleno careo con su padrastro, negó los cargos, argumentando que había mentido por miedo a que este la castigara por haber escapado, y todo lo redujo a que había tenido un "exceso de

${ }^{47}$ Mariano conocía a la familia desde hacía muchos años ya que había vivido con ellos un tiempo; testificó a favor de Amado pues nunca le observó "mala conducta". Al parecer, ambos comenzaron su carrera militar desde jóvenes y juntos anduvieron por Puebla, Veracruz y la ciudad de México. Causa instruida contra el sargento $1^{\circ}$ supernumerario de la $3^{a}$ compañía, Amado Flores, acusado de incesto en la persona de Luz Flores. Archivo de Guerra, vol. 32, exp. 261. AGN, México. 
acaloramiento". De lo que sucedió con esta joven no se sabe más, lo cierto es que, como ella, muchas mujeres difícilmente pudieron escapar de esta dinámica militar y familiar por demás violenta, y terminaron pasando de la autoridad del padre-sargento a la del esposo-soldado.

\section{CONCLUSIÓN}

Aunque "los hombres de bien" de la época vieron a estas mujeres y sus circunstancias con cierto desdén, advirtiendo que "tan extraños elementos" eran un "nocivo abuso" 48 para el ejército, no cabe duda que fueron importantes para los militares. Esta elite masculina dejó de ver a las mujeres de los soldados como "el sexo débil [...] amable y tiernamente considerado aun entre los más bárbaros", ${ }^{49}$ para ser un mal necesario que suministraba provisiones y otros servicios útiles a los miembros de las fuerzas armadas.

Existen numerosos testimonios que dan cuenta de la presencia de estas féminas en las instalaciones de los regimientos citadinos, cohabitando por las noches para satisfacer las necesidades elementales; a veces lo hicieron en espacios reducidos e insalubres, destinados a un número determinado de efectivos; e incluso, por las noches, esta cifra se veía triplicada con su presencia, además de la de niños y perros (Domingo y Barrera, 1880, pp. 38-40).

Las mujeres impregnaron aquel mundo castrense desatando numerosos sentimientos y opiniones por la forma como podían alterar o favorecer con su presencia aquel rudo mundo marcado por las armas y la violencia. En marcha con el ejército o acantonadas junto a sus instalaciones, acompañaron a sus hombres y vivieron la violencia de ellos, los celos, arrebatos y palizas como muestras de su dominio o posesión. Estableciendo aquellas relaciones de pareja dentro de una lógica patriarcal y compartiendo todo esto con las demás personas que se hallaban en torno al mundo militar: niños, hijas, hijastras, hermanas, madres y los subordinados.

Vistas como un mal necesario, su presencia fue creciendo hasta volverse un problema mayúsculo, al tiempo que adquirieron su propia personalidad, pues no importó si fueron las esposas, las amasias fugaces o las concubinas, todas pasaron a ser las soldaderas cuando se unían a los ejércitos para

${ }^{48}$ Frases del general Manuel Balbontín.

${ }^{49}$ Portada, El Mosquito Mexicano, 3 de junio de 1836. 
acompañar a sus hombres. Durante el segundo imperio trató de regularse su presencia y sus servicios, condicionando sus ingresos a quienes demostraran ser las esposas, pero sin mucho éxito.

Los médicos y algunos altos mandos se manifestaron sobre lo perjudicial de su presencia desde muy temprana época. Pero quizá los conflictos bélicos impidieron que pudieran ser erradicadas de los cuarteles, porque cumplían una importante función logística y de apoyo. En la década de los sesenta, hubo algunos mandos medios que impidieron la estadía de las mujeres para evitar que contagiaran a sus escuadrones, puesto que los reportes de los galenos ya las señalan directamente como un mal sanitario. Es posible que, en la época porfiriana, cuando médicos y científicos adquirieron preponderancia en la gestión gubernamental, comenzaron a aplicarse cambios radicales (por ejemplo inspecciones médicas de forma sistemática) para controlarlas y desterrarlas de los cuarteles, pues ya se veía el gran perjuicio económico y sanitario que ellas ocasionaban a la institución; destierro que además fue avanzando a la par de la profesionalización del ejército. De hecho, las soldaderas fueron responsabilizadas por extender los males venéreos entre las tropas, lo cual generaba gran intranquilidad entre los médicos militares. Y durante años fue difícil someterlas a todas a la revisión de los controles sanitarios, con el fin de erradicar la sífilis entre los militares (Carrillo, 2010, pp. 72-74).

Seducidas, engañadas, forzadas, robadas o enamoradas, todas ellas fueron enganchadas a un mundo masculino con su propia lógica. Imposibilitadas para volver a sus hogares y poblados de origen, prefirieron quedarse $y$ aprendieron a sobrevivir sirviendo a sus hombres y criando a sus hijos. Pero cuando la violencia de sus parejas las llevó ante las salas de los tribunales, vieron demeritar o ignorar muchas de sus quejas, para dar pie a la razón patriarcal, la conveniencia política, o el honor masculino, y, sobre todo, a la necesaria conservación de los efectivos militares por la importancia del ejército.

De la tolerancia institucional a la normalización, regularización y los intentos por su erradicación, al final, ellas serían parte del mundo de las armas. Vicente Riva Palacio ${ }^{50}$ nos ilustra su evolución: primero llegaban como mujeres tímidas y vergonzosas, sin establecer grandes relaciones con las demás mujeres de la tropa, sin conocer grados, ni insignias, cuando el "amor" por lo ajeno no se había arraigado en su corazón. Después de seis meses ya

\footnotetext{
50 Vicente Riva Palacio, “La soldadera”, México y sus Costumbres, 31 octubre de 1872, p. 2.
} 
formaban parte del regimiento, de la compañía o de la escuadra; ya eran consideradas "veteranas"; hablaban con el vocabulario de su hombre y al general lo llamaban "mi general", al coronel de su cuerpo "mi coronel", así también decían "mi mayor", "mi teniente", etc. A la mujer del tambor le llamaban la "mayora", a la del sargento, la "sargenta". "En cambio soldados, oficiales y jefes llaman a todas las mujeres de su tropa "las viejas"”.

Todas se proveían de víveres para el camino asaltando los gallineros. Cuando las tropas estaban formadas y listas para emprender la marcha, las soldaderas se hallaban atareadas previendo los suministros. Si el calor y el hambre azotaban a los soldados en marcha, ellas asistían con agua y comida, ayudaban a cargar el fusil para aliviar su cansancio. También veían al oficial que desfallecía de hambre o de sed, al soldado que no tenía quién lo auxiliara, al enfermo que estaba montado en un burro. Y cuando comenzaba la batalla, se escabullían entre balas y cañonazos para llevar agua, auxiliar a sus hombres, asistir a un herido, desvestir a los muertos.

La soldadera se quedaba siempre en la misma condición; si salía herida o enferma en una campaña y llegaba moribunda a un poblado con el batallón, a la mañana siguiente no llegaba al cuartel. Si dejaba algún huérfano, este se quedaba a cargo de las demás soldaderas. Las tropas se alejaban y nadie volvía a pensar en aquella mujer ignorada, "conjunto inexplicable de heroicas virtudes y de vicios repugnantes". ${ }^{51}$

\section{LISTA DE REFERENCIAS}

Balbontín, M. (1867). Apuntes sobre un sistema militar para la república. Obra dedicada al supremo gobierno nacional. México: Imprenta de Ignacio Cumplido.

Ceja Andrade, C. (2018). Una mirada de las fuerzas armadas de la ciudad de México a través de las hojas de filiación y los procesos militares, 1824-1859. Tzintzun. Revista de Estudios Históricos, 68, 77-103. Recuperado de http://www.scielo.org.mx/scielo. php?script=sci_arttext\&pid=S1870-719X2018000200077\&lng=es\&tlng=es

Carrillo A. M. (2010). Control sexual para el control social. La primera campaña contra la sífilis en México. Espaço Plural, XI(22), 65-77. Recuperado de https://www. redalyc.org/articulo.oa?id $=445944364008$

${ }^{51}$ Vicente Riva Palacio, "La soldadera", México y sus costumbres, 31 octubre de 1872, p. 2. 
Correa Mosquera, N. R. y Cáceres Cabrales, M. A. (2012). Los soldados y las mujeres de las castas. Vida cotidiana y matrimonios de la soldadesca del ejército colonial en Cartagena en el siglo xviII. Revista Historia 2.0. Conocimiento Histórico en Clave Digital, 2(4), 48-59. Recuperado de https://dialnet.unirioja.es/servlet/articulo?codigo $=4095474$

Domingo y Barrera, F. (1880). Ligero estudio sobre higiene de cuarteles e indicación de las condiciones que guardan los de la capital y medios que se dan para mejorarlos. (Alumno de la Escuela de Medicina de México, ex practicante del Hospital Juárez y aspirante del cuerpo de sanidad militar). México: Tipografía literaria de Filomeno Mata.

García Figueroa, A. (1874). Higiene militar. Causas de la frecuencia de la sífilis en el ejército y medios de disimularla. Alumno de la escuela de medicina de México, y aspirante médico-militar del hospital de instrucción en San Lucas. México: Imprenta de Ignacio Escalante.

García Peña, A. L. (2004). Madres solteras, pobres y abandonadas: ciudad de México, siglo xIX. Historia Mexicana, LIII(3), 647-692. Recuperado de https://historiamexicana.colmex.mx/index.php/RHM/article/view/1440

García Peña A. L. (2006). El fracaso del amor. Género e individualismo en el siglo XIX mexicano. México: El Colegio de México/Universidad Autónoma del Estado de México.

Gómez, M. C. (1992). El sistema defensivo americano. España: Mapfre.

Guardino, P. (2018). La marcha fúnebre: una historia de la guerra entre México y Estados Unidos. México: Instituto de Investigaciones Históricas-UnAM.

Martínez Calleja, F. (1887). Ligeras consideraciones médicas sobre el ejército. México: Tipografía de El Socialista.

Ordenanza militar (1833, t. I). México: Imprenta de Galván a cargo de Mariano Arévalo.

Ordenanza militar para el régimen, disciplina, subordinación y servicio del ejército, aumentada con las disposiciones relativas anteriores y posteriores a la independencia, con las tarifas de haberes, formularios de la plana mayor (1842, t. II). México: Imprenta de José M. Lara.

Ordenanza militar para el régimen, disciplina, subordinación y servicio del ejército, comparada, anotada y ampliada. Por lo que se observaba al verificarse la independencia, con las disposiciones anteriores y posteriores hasta el presente año, en que revisada previamente por la junta consultiva de guerra, se publica por disposición del supremo gobierno (1852, t. III). México: Imprenta de Vicente G. Torres.

Repertorio de literatura y variedades (1842). México: Imprenta de Miguel González. Recuperado de https://repositorio.unam.mx/844221 
Rodríguez, A. J. (1891, 1 de enero). Profilaxis de las afecciones venéreo-sifilíticas en el ejército, por el mayor médico-cirujano Ángel J. Rodríguez. Gaceta Médico Militar, III, 192-203.

Stern, S. J. (1999). La historia secreta del género: Mujeres, hombres y poder en México en las postrimerías del periodo colonial. México: Fondo de Cultura Económica.

Tuñón, J. (2008). Enjaular los cuerpos. Normatividad decimonónica y feminidad en México. México: El Colegio de México.

Urquizo, F. L. (1943). Tropa vieja. México: Talleres Gráficos del Depto. de Publicidad y Propaganda de la seP.

\section{OTRAS FUENTES}

\section{Hemerografía}

Diario de Avisos, 1857.

El Demócrata, 1895.

El Foro. Periódico de Jurisprudencia y de Legislación, 1873.

El Monitor Republicano, 1872.

El Mosquito Mexicano, 1836.

El Nacional, 1887.

El Siglo Diecinueve, 1863.

La Sociedad. Periódico Político y Literario, 1863.

La Voz de México. Diario Político, Religioso, Científico y Literario de la "Sociedad Católica", 1874.

México y sus Costumbres, 1872.

Periódico Militar, 1879. 